\title{
Landslide hazard zonation mapping and cut slope stability analyses along Yercaud ghat road (Kuppanur-Yercaud) section, Tamil Nadu, India
}

\author{
V. Ramesh ${ }^{1,2}$, S. Mani ${ }^{1,3}$, M. Baskar ${ }^{1}$, G. Kavitha ${ }^{1}$ and S. Anbazhagan ${ }^{{ }^{*}}$
}

*Correspondence:

anbu02@gmail.com

${ }^{1}$ Centre for Geoinformatics and Planetary Studies, Periyar University, Salem, Tamil Nadu 636011 , India

Full list of author information is available at the end of the article

\begin{abstract}
In the present study, the macro landslide hazard zonation (LHZ) mapping and slope stability analyses of selected rock slope (RS) sections were carried out along KuppanurYercaud ghat road section. The macro LHZ map was prepared on 1:50,000 scale using landslide hazard evaluation factor (LHEF) rating scheme proposed by Bureau of Indian Standard IS 14496 (Part-2) 1998. The study incorporated predefined ratings for different causative factors viz. lithology, structure, slope morphometry, relative relief, land use and land cover, and hydrogeological condition as well as triggering factors like seismicity and rainfall. The total estimated hazard (TEHD) was evaluated by adding ratings of all the causative factors. On the basis of TEHD values, the facet 3 with TEHD value 6.25 was classified as high hazard zone (HHZ). The facet 2 and 4 with TEHD values 5.50 and 5.40 respectively was classified as moderate hazard zones (MHZ). The facet 1 and 5 with TEHD values 2.20 and 3.15 was categorized as very low hazard zone (VLHZ). The slope stability analyses were carried out in six RS sections using rock mass rating (RMR) and slope mass rating (SMR) systems and the factor of safety (FOS) was evaluated for critical discontinuity sets. The results of RMR show that RS sections 1,2, 4, 5, and 6 fall in class-III fair rock category, whereas the RS section 3 falls in class-IV poor rock category. The SMR method involves field measurement of slope and discontinuity orientation. These structural values were plotted in the stereonet and identified possible direction and mode of failure. The results of SMR show that the rock sections 1, 2, 4, 5, and 6 falls under partially stable condition, while the rock section 3 comes under unstable condition. The FOS of the critical discontinuity sections was evaluated for planar as well as wedge failure modes. The results based on planar failure analysis, the RS-2 and RS-3 having FOS $<1$ are more unstable for slope failure. The wedge failure analysis shows that all the RS sections having FOS $>1$ fall in safe conditions.
\end{abstract}

Keywords: Landslide hazard zonation, Slope stability analyses, LHEF rating scheme, Rock mass rating (RMR), Slope mass rating (SMR), Factor of safety (FOS)

\section{Background}

Landslide is an important natural calamity, which frequently occurs on natural slopes as well as cut slopes of ghat roads in mountainous region, causing risk to human life and properties each year $[2,45]$. The occurrence of landslides in mountainous regions is

(c) The Author(s) 2017. This article is distributed under the terms of the Creative Commons Attribution 4.0 International License (http://creativecommons.org/licenses/by/4.0/), which permits unrestricted use, distribution, and reproduction in any medium, provided you give appropriate credit to the original author(s) and the source, provide a link to the Creative Commons license, and indicate if changes were made. 
subjected to influence of different causative factors and are triggered by rainfall, earthquake shaking, water level change, storm waves and rapid stream erosion etc. [18, 46]. In addition, the anthropogenic activities on hill slope such as construction of roads, urban expansion, deforestation, and changes on land use practices increases the landslide occurrences [19]. The discrimination and mitigation of landslide prone areas in a region are essential for future planning and developmental activities. Globally, the governments as well as several research institutions have been spending significant resources to assess the landslide hazards and their spatial distribution [26]. The evaluation of landslide hazard is a vital task for different interest groups such as geoscientists, planners and local administrations, because of the situation of increased awareness and the socio-economic impact of landslides [21]. Landslide hazard refers to the possibility of occurrence of certain type and magnitude of landslide at a particular location within a specified period of time. LHZ mapping involves the discrimination of identical areas of varying hazard levels based on degrees of actual or potential damage [77]. LHZ map shows probable areas of landslide occurrence and useful for better land use planning and the progress of suitable remedial measures. The LHZ map can be used for developmental activities and management of natural resources in an area [76].

Landslide hazard and susceptibility zonation mapping have been carried out by using various methods and techniques using different scales based on the requirement of the end user and the rationale of the investigation [26]. Different landslide hazards and susceptibility mapping methods described by Mantovani et al. [39] include distribution analysis [16, $22,78]$, qualitative analysis $[17,41,43]$, statistical analysis $[53,55,67]$, deterministic analysis $[1,6,44,68]$, landslide frequency analysis $[12,32,40,42]$, and distribution-free methods such as fuzzy logic $[34,36,52-54,69]$ and artificial neural network (ANN) models [13, 15, 51, 80]. Many researchers adopted the Bureau of Indian Standard [BIS 14496 (Part 2): 1998] guidelines to prepare the landslide hazard zonation mapping [5]. The BIS guidelines [11] were originally proposed by Anbalagan [3], which suggest a quantitative method based on conventional field surveys called landslide hazard evaluation factor (LHEF) rating scheme for Himalaya region. Number of researchers have carried out the landslide hazard zonation mapping based on LHEF rating scheme on different scales using varying number of parameters with some revision for different terrains $[4,5,33,35,60-62,65]$.

In mountainous region, the inappropriate modification adopted on natural slope condition for the purpose of construction and widening of the transportation network affects the stability of the cut slope [68]. The understanding and analyses of geotechnical characteristics of soil and rock give the possibility of occurrence of landslide in a specific site. The stability of a required and existing rock slope can evaluate rapidly and reliably using rock mass classification systems [70] on the basis of structural and other geotechnical parameters [49]. The geomechanical classification or the RMR system was first proposed by Bieniawski [8] for the application of stability assessment for designing tunnels, mine, dam, and underground excavations. The RMR system in the evaluation of slope stability was introduced by Bieniawski [9]. Different geomechanical classification systems have been proposed to assess the slope stability of a rock mass [73] which includes, rock mass strength [63], slope mass rating system [57], slope rock mass rating [56], rock mass rating [10], mining rock mass rating [37], mining rock mass rating modified [29], natural slope methodology [66], chinese slope mass rating [14], modified rock mass rating [75], slope 
stability probability classification [27, 28], slope stability probability classification modified [38], continuous rock mass rating [64], continuous slope mass rating [72, 74] and an alternative rock mass classification system proposed by Pantelidis [50]. The SMR is the commonly used classification system globally [59] and can be derived from the $\mathrm{RMR}_{\text {basic }}$ [10]. The RMR $_{\text {basic }}$ and SMR classifications system provides a specific rating for individual parameter and describes the slope stability in terms of total $R_{M R} R_{\text {basic }}$ and $S M R$ values.

The BIS guidelines [11] for LHZ mapping in mountainous terrain at medium scale $(1: 50,000)$ were used in the present study. The LHZ map was prepared for the Kuppanur-Yercaud ghat road section using LHEF rating scheme [11], which suggests indirect heuristic (knowledge-driven) method to LHZ mapping without taking into consideration of landslide inventory data [23]. The ghat road section covers small aerial extent, hence the technique is more appropriate to evaluate the causative factors through field surveys. The cut slope stability assessment of rock slopes was also assessed along this ghat road section at selected locations using RMR system [10] and SMR system [58]. The FOS for the critical rock slope sections was calculated by using Hoek and Bray [31] method.

\section{Study area}

Yercaud hill is one of the important tourist spots in Tamil Nadu, situated in Shervaroys hills of Salem district, Tamil Nadu. The hilly region is connected by ghat road section constructed with minor hairpin bends. The length of the ghat road is $27 \mathrm{~km}$, which connects the foot hills at Kuppanur to Yercaud at top of the hill. This $27 \mathrm{~km}$ ghat road crosses the settlements Kotanchedu, Kirakadu, and Sengadu. The general relief of the Yercaud (Alternate) ghat section is ranges from 400 to $1450 \mathrm{~m}$ above mean sea level (AMSL). The lowest altitude of $400 \mathrm{~m}$ is present near the Yercaud foothills (Kuppanur Village). The highest altitude of $1450 \mathrm{~m}$ is present near the Longlipettai area. The annual rainfall ranges between 1500 and $2000 \mathrm{~mm}$. The $12 \mathrm{~km}$ ghat road sections from Kuppanur to Kottanchedu have many vertical rock and soil slopes with considerable slope height has chosen for the present study. The remaining section of the road constructed nearly parallel to the contour and drainage, hence there are no cut slopes found. The area falls in between $11^{\circ} 44^{\prime} 31^{\prime \prime} \mathrm{N}$ and $11^{\circ} 47^{\prime} 2^{\prime \prime} \mathrm{N}$ latitudes and $78^{\circ} 15^{\prime} 28^{\prime \prime} \mathrm{E}$ and $78^{\circ} 16^{\prime} 39^{\prime \prime} \mathrm{E}$ longitudes. The Survey of India (SOI) topographical map series numbers 58 I/5 and 58 I/6 is covering the study area (Fig. 1). This ghat road section is an alternative route to reach the Yercaud hills. The geological setting in the study area has shown that highly fissile charnockite and gneiss with area covered by smaller ultramafic rock of serpentinedunite in the southwestern part (GSI [25]. The hill top is a plateau region marked by high peaks and undulating terrain. In addition, the hill comprises of steep slopes, gullies, valleys and fractures.

\section{Methods and parameters}

\section{LHEF rating scheme}

The LHZ map was prepared based on the guidelines of BIS code [IS 14496 (Part 2): 1998]. The BIS guidelines is a Indian standard developed for the purpose of preparation of LHZ maps in mountainous terrains. The method and procedure described in BIS guidelines is LHEF rating scheme. The LHEF rating scheme is a numerical system, which 


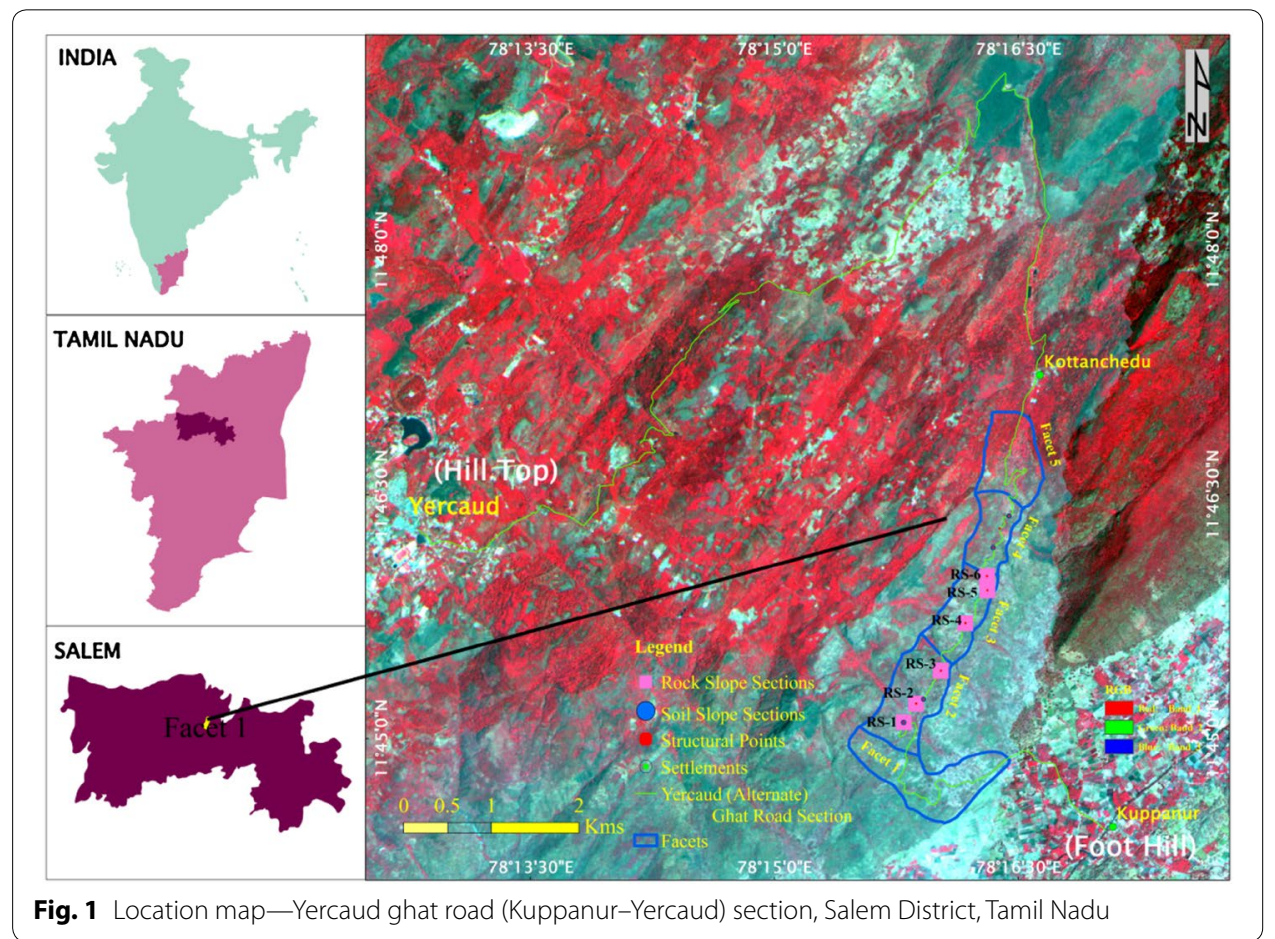

describes the slope instability in terms of cumulative effect of the major causative factors of the slope instability [11]. The lithology, structure, slope morphometry, relative relief, land use and land cover, and hydrogeological condition are the major parameters considered in the LHEF rating scheme. Apart from six in-built causative factors, the triggering factors like seismicity and rainfall were also included in LHEF rating scheme [4]. The facet-wise analyses were carried out on causative factors according to the maximum LHEF rating given in Table 1. The ratings for the sub-categories in each causative factor were assigned using the LHEF rating scheme given in BIS guidelines (Table 2).

A slope facet is the smallest section which is divided using ridges, spurs, gullies and rivers for the analysis of each causative factor in LHEF rating scheme. It is a part of hill slope which has more or less identical characteristics of slope, showing regular slope

Table 1 Maximum LHEF rating for causative factors (source: [4, 11])

\begin{tabular}{lc}
\hline Causative factor & Maximum \\
\hline Lithology & 2.0 \\
Structure & 2.0 \\
Slope morphometry & 2.0 \\
Relative relief & 0.5 \\
Land use and land cover & 2.0 \\
Hydrogeological condition & 1.5 \\
Correction due to triggering factors (to be added separately to the total of LHEF) & \\
a) Seismicity & 0.5 \\
b) Rainfall & 0.5 \\
Corrected LHEF rating & 11.0
\end{tabular}


Table 2 Landslide hazard evaluation factor (LHEF) rating scheme (Source: [5, 11])

\begin{tabular}{lll}
\hline Contributory factor & Category & Rating \\
\hline $\begin{array}{ll}\text { A. Lithology } \\
\text { (i) Rock type }\end{array}$ & Type-I & \\
& Quartzite and limestone & 0.20 \\
& Granite and gabbro & 0.30 \\
& Gneiss & 0.40 \\
& Type-II & 1.00 \\
& Well cemented sedimentary rock dominantly sandstone with & \\
& minor beds of clay stone & 1.30 \\
& Poorly cemented terrigenous sedimentary rock dominantly & 1.20 \\
& sandstone with minor clay shale beds & 1.30 \\
& Type-III & 1.80 \\
& Slate and phyllite & 2.00 \\
& Schist & 0.80 \\
& Shale with interbedded clayey and non-clayey rocks & 1.00 \\
& Highly weathered shale, phyllite and schist & 1.40 \\
& Older well compacted alluvial fill material & \\
& Clayey soil with naturally formed surface & \\
Sandy soil with naturally formed surface (alluvial) & \\
& Debris comprising mostly rock pieces mixed with clayey/sandy & 1.20 \\
& soil (colluvial) \\
& Older well compacted & 2.00
\end{tabular}

Remarks - correction factor for weathering of rock

Highly weathered — rock discoloured, joints open with weathered products, rock fabric altered to a large extent-correction factors $\mathrm{C} 1$

Moderately weathered_-rock discoloured with fresh rock patches, weathering more around joint planes, but rock in-tact in nature - correction factor C2

Slightly weathered_-rock slightly discoloured along joint planes, which may be moderately tight to open, intact rock-correction factor $\mathrm{C} 3$

The correction factor for weathering to be multiplied with the fresh rock rating

For rock type 1: $C_{1}=4, C_{2}=3, C_{3}=2$

For rock type $2: C_{1}=1.5, C_{2}=1.25, C_{3}=1.0$

B. Structure

(i) Relationship of parallelism between the slope and the discontinuity

Planar $\left(a_{i}-a_{s}\right) \quad$ ।

Wedge $\left(a_{i}-a_{s}\right) \quad$ ॥

$>30^{\circ} \quad 0.20$

॥

$21^{\circ}-30^{\circ} \quad 0.25$

IV

$11^{\circ}-20^{\circ} \quad 0.30$

IV

$6^{\circ}-10^{\circ} \quad 0.40$

$\mathrm{V}$

$<5^{\circ} \quad 0.50$

(ii) Relationship of dip of discontinuity and inclination of slope

Planar $\left(\beta_{i}-\beta_{s}\right)$

Wedge $\left(\beta_{i}-\beta_{s}\right)$

\section{।}

$\|$

III

IV

$\checkmark$

$>10^{\circ} \quad 0.30$

$0^{\circ}-10^{\circ} \quad 0.50$

$0^{\circ} \quad 0.70$

$0^{\circ}-(-) 10^{\circ} \quad 0.80$

$>(-) 10^{\circ} \quad 1.00$

(iii) Dip of discontinuity

Planar $\left(\beta_{i}-\beta_{s}\right)$

Wedge $\left(\beta_{i}-\beta_{s}\right)$

IV $\quad 36^{\circ}-45^{\circ} \quad 0.40$

$\begin{array}{lll}V & >45^{\circ} & 0.50\end{array}$


Table 2 continued

\begin{tabular}{llll}
\hline Contributory factor & Category & & Rating \\
\hline (iv) Depth of soil cover & $<5 \mathrm{~m}$ & 0.65 \\
& $6-10 \mathrm{~m}$ & 0.85 \\
& $11-15 \mathrm{~m}$ & 1.30 \\
& $16-20 \mathrm{~m}$ & 2.00 \\
& $>20 \mathrm{~m}$ & 1.20
\end{tabular}

Remarks - discontinuity refers to the planar discontinuity or the line of intersection of two planar discontinuities whichever is important from the point of view of instability

$a_{j}=$ Dip direction of joint; $a_{s}=$ Direction of slope inclination;

$a_{i}=$ Direction of line of intersection of two discontinuities; $\beta_{\mathrm{j}}=$ Dip of joint;

$\beta_{\mathrm{s}}=$ Inclination of slope; $\beta_{\mathrm{i}}=$ Plunge of line intersection of two discontinuities

Category $\mid$ = very favourable; $\|$ = favourable; $I I=$ fair; IV = unfavourable; $V=$ very unfavourable

C. Slope morphometry

D. Relative relief

$\begin{array}{lll}\text { Escarpment/cliff } & \geq 45^{\circ} & 2.0 \\ \text { Steep slope } & 36^{\circ}-45^{\circ} & 1.7 \\ \text { Moderately steep slope } & 26^{\circ}-35^{\circ} & 1.2 \\ \text { Gentle slope } & 16^{\circ}-25^{\circ} & 0.8 \\ \text { Very gentle slope } & \leq 15^{\circ} & 0.5 \\ & & \\ \text { Low } & <100 \mathrm{~m} & 0.3 \\ \text { Medium } & 101-300 \mathrm{~m} & 0.6 \\ \text { High } & >300 \mathrm{~m} & 1.0\end{array}$

Remarks - In regions of low seismic activity (1,2 and 3 zones), the maximum rating for relative relief may be reduced to 0.5 and that of hydrogeological conditions be increased to 1.5 (Table 1). Accordingly the detailed ratings of these contributory factors (Table 2) may be multiplied by 0.5 and 1.5 respectively. For seismic zones 4 and 5, no corrections are required.

E. Land use and land cover

Agricultural land/populated flat land $\quad 0.6$

Thickly vegetated forest area $\quad 0.8$

Moderately vegetated area $\quad 1.2$

Sparsely vegetated area with lesser ground cover $\quad 1.5$

Barren land $\quad 2.0$

F. Hydrogeological conditions

$\begin{array}{ll}\text { Flowing } & 1.0 \\ \text { Dripping } & 0.8 \\ \text { Wet } & 0.5 \\ \text { Damp } & 0.0 \\ \text { Dry } & 0.2\end{array}$

amount and direction. In the present study, the Kuppanur-Yercaud ghat road section was divided into slope facets for assessment of individual LHEF. There were five facets with homogeneous terrain conditions was divided using topographical map based on slope inclination, relief (elevation difference), and slope direction.

The rock type and its resistance to the weathering and erosion process is one of the significant aspects in controlling slope stability [48]. The lithology map was prepared from the district resource map published by Geological Survey of India [24]. The charnockite is the main lithological unit in the study area. Hence, the ratings were evaluated by applying weathering condition of rocks in each facet. The geological structures such as bedding planes, joints, foliations, faults and thrusts are the discontinuities associated 
with the in situ rocks over hill slopes, which play a major role in the occurrence of landslides. The relationship between the structural discontinuities and slope inclination has greater influence on slope instability. The relationships given in the LHEF scheme are (1) parallelism between the direction of slope and the discontinuity, (2) dip of discontinuity and inclination of slope, (3) dip of discontinuity [61]. The structural ratings for each facet were evaluated from the structural relationships of discontinuities with slope. In case of soil and debris slopes, the ratings were assigned based on the depth of soil and overburden. The structural point (SP) and soil slope point locations are shown in Fig. 1.

Slope morphometry map shows the different classes based on the frequency of occurrence of particular angles of slope [11]. The same number of contour lines per kilometre of horizontal distance exists within a facet was evaluated. In LHEF rating scheme, five different slope categories were used to represent the slopes; escarpment and cliff $\left(>45^{\circ}\right)$, steep slope $\left(36^{\circ}-45^{\circ}\right)$, moderately steep slope $\left(26^{\circ}-35^{\circ}\right)$, gentle slope $\left(16^{\circ}-25^{\circ}\right)$ and very gentle slope $\left(<15^{\circ}\right)$. The temperature decline and rainfall affect the natural conditions at higher elevations, which support the occurrence of landslides [7]. Relative relief determines the maximum height of a facet from minimum value to maximum value measured along slope direction for each facet was evaluated using the topographical map. In LHEF rating scheme, three relative relief categories are described as low $(<100 \mathrm{~m})$, medium (101-300 $\mathrm{m})$ and high relative relief $(>300 \mathrm{~m})$ zone.

Vegetation cover protects and controls the slope from the soil erosion and landslides [71]. Hence, it is necessary to consider the land use and land cover factor in landslide studies. The land use and land cover map were interpreted using ResourceSat2 LISS IV satellite image with the spatial resolution of $5.8 \mathrm{~m}$ and topographical map.

The hydrological properties of an area controlled by streams, rivers, underground water, saturation state of rocks/soils, and drainage pattern present in an area play a vital role in slope failure [35]. In hilly terrain, irregular flow of groundwater in rock slopes along structural discontinuities decreases shear strength of slope forming material and increases the possibility of slope failure. This irregular flow of groundwater seeps out and could be identified as surface indications along cut slope sections. The LHEF scheme suggests a direct method of field observation to identify the surface indication of hydrogeological conditions visually as flowing, dripping, wet, damp and dry and the ratings were assigned accordingly. It is desirable to take field data soon after the monsoon season [4].

The facet-wise LHEF ratings were evaluated for all the causative factors to calculate the total estimated hazard (TEHD). The ratings for seismicity and rainfall were added with TEHD to evaluate the final TEHD values for each facet. On the basis of final TEHD values, five classes of landslide hazard zones were classified as very low (TEHD < 3.5), low (3.515.0), moderate (5.01-6.5), high (6.51-8.0) and very high (TEHD > 8.01) hazard zones [4].

\section{Rock mass rating $\left(\mathrm{RMR}_{\text {basic }}\right)$ system}

The RMR $\mathrm{R}_{\text {basic }}$ system [10] considered five parameters viz. Uniaxial Compressive Strength (UCS), Rock Quality Designation (RQD), spacing of discontinuities, condition of discontinuities, and groundwater conditions and its ratings (Table 3). A maximum RMRbasic value is 100, which can be obtained by adding the ratings of individual parameters. Based on the total $\mathrm{RMR}_{\text {basic }}$, five classes are defined in the system as very poor rock (class V: 0-20), poor rock (class IV: 20-40), fair rock (class III: 40-60), good rock (class 


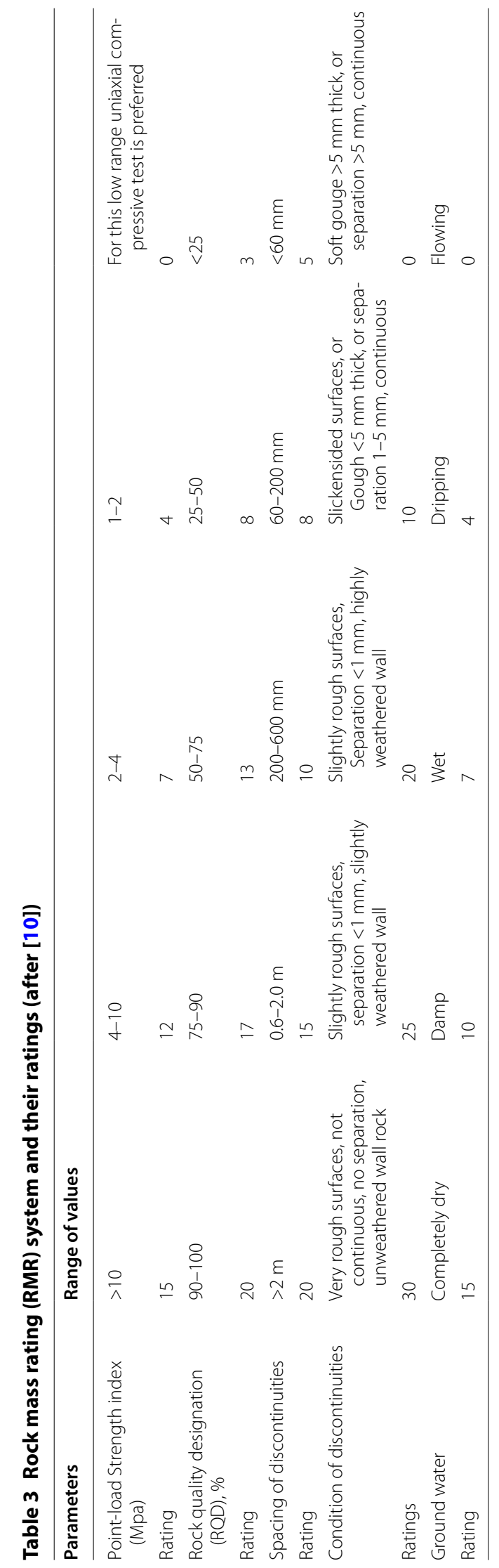


II: 60-80), and very good rock (80-100). The point load test was carried out using AIM206-1 testing machine and the strength index was calculated using the Eq. (1)

$$
\mathrm{I}_{\mathrm{L}(50)}=\mathrm{P} /(\mathrm{DW})^{0.75} \sqrt{\mathrm{D}} \mathrm{MN} / \mathrm{m}^{2}
$$

where, $\mathrm{I}_{\mathrm{L}(50)}$ - point load lump strength index in $\mathrm{kgf} / \mathrm{cm}^{2} ; \mathrm{P}$-Peak load at failure in $\mathrm{kgf}$; DW-the minimum cross sectional area in $\mathrm{cm}^{2}$; D-mean cross sectional thickness of specimen in $\mathrm{cm}$; W-mean width of specimen in $\mathrm{cm}$; D-standard size of lump $(5 \mathrm{~cm})$.

The RQD was evaluated through volumetric joint count method i.e. sum of the number of joints per metre cube (unit volume) for all joint sets [47] as given in Eq. (2)

$$
\mathrm{RQD}=115-3.3 \mathrm{Jv}
$$

where, Jv is the sum of the number of joints per metre cube for all joint (discontinuity) sets.

The term discontinuity covers joints, beddings or foliations, shear zones, minor faults, or other surfaces of weakness, which are common features in rock masses [20]. Discontinuity spacing measures the distance between two adjacent discontinuities should be measured for all sets of discontinuities [79]. Discontinuity condition measures the discontinuity length, separation, roughness, infilling, and weathering condition of weak planes are measured in the field. The groundwater condition of a particular slope is completely dry, damp, wet, dripping and flowing, which can be measured based on nature of surface indications $[3,11]$.

\section{Slope mass rating (SMR) system}

The SMR system proposed by Romana [58], a modification to the RMR basic system, can be obtained from the $\mathrm{RMR}_{\text {basic }}$ by adding resultant adjustment factors (Table 4) from

\begin{tabular}{|c|c|c|c|c|c|c|}
\hline Case & & $\begin{array}{l}\text { Very } \\
\text { favorable }\end{array}$ & Favorable & Fair & Unfavorable & $\begin{array}{l}\text { Very } \\
\text { unfavorable }\end{array}$ \\
\hline P & $\left|a_{j}-a_{s}\right|$ & $>30^{\circ}$ & $30^{\circ}-20^{\circ}$ & $20^{\circ}-10^{\circ}$ & $10^{\circ}-5^{\circ}$ & $<5^{\circ}$ \\
\hline W & $\left|a_{i}-a_{s}\right|$ & & & & & \\
\hline $\mathrm{T}$ & $\left|a_{i}-a_{s}-180^{\circ}\right|$ & & & & & \\
\hline $\mathrm{P} / \mathrm{T} / \mathrm{W}$ & $\mathrm{F} 1$ & 0.15 & 0.40 & 0.70 & 0.85 & 1.00 \\
\hline $\mathrm{P} / \mathrm{W}$ & $\begin{array}{l}\left|\beta_{\mathrm{j}}\right| \\
\left|\beta_{\mathrm{i}}\right|\end{array}$ & $<20^{\circ}$ & $20^{\circ}-30^{\circ}$ & $30^{\circ}-35^{\circ}$ & $35^{\circ}-45^{\circ}$ & $>45^{\circ}$ \\
\hline $\mathrm{P} / \mathrm{W}$ & $\mathrm{F} 2$ & 0.15 & 0.40 & 0.70 & 0.85 & 1.00 \\
\hline $\mathrm{T}$ & $\mathrm{F} 2$ & 1.00 & 1.00 & 1.00 & 1.00 & 1.00 \\
\hline $\begin{array}{l}P \\
W\end{array}$ & $\begin{array}{l}\beta_{j}-\beta_{s} \\
\beta_{i}-\beta_{s}\end{array}$ & $>10^{\circ}$ & $10^{\circ}-0^{\circ}$ & $0^{\circ}$ & $0^{\circ}-\left(-10^{\circ}\right)$ & $<-10^{\circ}$ \\
\hline $\mathrm{T}$ & $\beta_{j}+\beta_{s}$ & $<110^{\circ}$ & $110^{\circ}-120^{\circ}$ & $>120^{\circ}$ & - & - \\
\hline $\mathrm{P} / \mathrm{T} / \mathrm{W}$ & F3 & 0 & -6 & -25 & -50 & -60 \\
\hline \multirow[t]{2}{*}{$\begin{array}{l}\text { Adjustment } \\
\text { factors for } \\
\text { method of } \\
\text { excavation }\end{array}$} & $\mathrm{F} 4$ & $\begin{array}{c}\text { Natural } \\
\text { slope }\end{array}$ & Presplitting & $\begin{array}{l}\text { Smooth } \\
\text { blasting }\end{array}$ & $\begin{array}{c}\text { Mechanical } \\
\text { excavation }\end{array}$ & Poor blasting \\
\hline & & +15 & +10 & +8 & 0 & -8 \\
\hline
\end{tabular}

Table 4 Ratings for adjustment factors (after [58])

P, planar failure; $W$, wedge failure; $T$, toppling failure, $a_{j}$, dip direction Joint; $a_{i}$, direction of line of intersection of two discontinuities, $a_{s^{\prime}}$ direction of slope inclination, $\beta \mathrm{s}$, inclination of slope, $\beta_{\mathrm{j}}$, dip of joint, $\beta_{\mathrm{i}}$ plunge of line of intersection of two discontinuities 
joint-slope relationship and method of excavation as given in Eq. (3). The SMR system describes five different stability classes based on total SMR values as completely stable (80-100), stable (60-80), partially stable (40-60), unstable (20-40) and completely unstable $(<20)$.

$$
\mathrm{SMR}=\mathrm{RMR}_{\text {basic }}+(\mathrm{F} 1 * \mathrm{~F} 2 * \mathrm{~F} 3)+\mathrm{F} 4
$$

where, $R M R_{\text {basic }}$ is rock mass rating value; $F_{1}$ depends on parallelism between joints and slope face strikes; $F_{2}$ refers to joint dip angle in the planar mode of failure; $F_{3}$ states the relationship between the slope face and joint dips; $F_{4}$ the adjustment factor for the method of excavation

\section{Factor of safety (FOS)}

The kinematic analysis is an important task in stability analyses, which includes the determination of mode and direction of failure. The relationship of orientations of the discontinuity with the slope face gives the critical discontinuity set and the possible mode and direction of failure. The relationship can be evaluated through the analysis of stereographic projections, which is plotted using the geometry of discontinuity and slope measured in the field. The planar and wedge type of slope failures are most general types commonly occurred in rock mass influenced by discontinuities. The planar failure occurs, when a discontinuity strikes parallel or nearly parallel to the slope face and dips into the excavation at an angle greater than the angle of friction. The FOS for the planar failure case can be evaluated using Eq. (4) which is total force resisting sliding to the total force tending to induce sliding [31].

$$
\mathrm{F}=\frac{\left(\frac{2 \mathrm{c}}{\gamma \mathrm{H}}\right) \cdot \mathrm{P}+(\mathrm{Q} \cdot \operatorname{Cot} \Psi \mathrm{p}-\mathrm{R}(\mathrm{P}+\mathrm{S})) \operatorname{Tan} \Phi}{\mathrm{Q}+\mathrm{R} \cdot \mathrm{S} \operatorname{Cot} \Psi \mathrm{p}}
$$

where,

$$
\begin{aligned}
& \mathrm{P}=\left(1-\frac{\mathrm{z}}{\mathrm{H}}\right) \cdot \operatorname{Cosec} \Psi_{\mathrm{p}} \\
& \left.\mathrm{Q}=\left(\left(1-(\mathrm{z} / \mathrm{H})^{2} \operatorname{Cot} \Psi_{\mathrm{p}}-\operatorname{Cot} \Psi_{\mathrm{f}}\right) \operatorname{Sin} \Psi_{\mathrm{p}}\right)\right) \\
& \mathrm{R}=\frac{\gamma_{\mathrm{w}}}{\gamma} \cdot \frac{\mathrm{Z}_{\mathrm{w}}}{\mathrm{Z}} \cdot \frac{\mathrm{Z}}{\mathrm{H}} \\
& \mathrm{S}=\frac{\mathrm{Zw}}{\mathrm{Z}} \cdot \frac{\mathrm{Z}}{\mathrm{H}} \cdot \operatorname{Sin} \Psi_{\mathrm{p}}
\end{aligned}
$$

The $\mathrm{P}, \mathrm{Q}, \mathrm{R}$ and $\mathrm{S}$ are all dimensionless ratios i.e. they depend upon the geometry but not upon the size of the slope; $\mathrm{c}-$ cohesion; $\mathrm{z}$-height of tension crack; $\mathrm{H}-$ height of the slope; $\Phi$-angle of friction 
The wedge failure occurs along the line of intersection of two discontinuity planes [31]. The FOS of this slope can be derived from the Eq. (9) given by Hock et al. [30].

$$
\mathrm{F}=\frac{3}{\gamma \mathrm{H}}\left(\mathrm{c}_{\mathrm{A}} \cdot \mathrm{X}+\mathrm{c}_{\mathrm{B}} \cdot \mathrm{Y}\right)+\left(\mathrm{A}-\frac{\gamma_{\mathrm{W}}}{2 \gamma} \cdot \mathrm{X}\right) \operatorname{Tan} \Phi_{\mathrm{A}}+\left(\mathrm{B}-\frac{\gamma_{\mathrm{W}}}{2 \gamma} \cdot \mathrm{Y}\right) \operatorname{Tan} \Phi_{\mathrm{B}}
$$

where, $\mathrm{c}_{\mathrm{A}}$ and $\mathrm{c}_{\mathrm{B}}$ are the cohesive strengths of planes $\mathrm{A}$ and $\mathrm{B} ; \Phi_{\mathrm{A}}$ and $\Phi_{\mathrm{B}}$ are the angles of friction on planes $A$ and $B ; \gamma$ is the unit weight of the rock; $\gamma_{W}$ is the unit weight of water; $\mathrm{H}$ is the total height of the wedge.

$$
\begin{aligned}
& X=\frac{\operatorname{Sin} \theta_{24}}{\operatorname{Sin} \theta_{45} \cdot \operatorname{Cos} \theta_{2 . n a}} \\
& Y=\frac{\operatorname{Sin} \theta_{13}}{\operatorname{Sin} \theta_{35} \cdot \operatorname{Cos} \theta_{1 . n b}} \\
& A=\frac{\operatorname{Cos} \Psi_{a}-\operatorname{Cos} \Psi_{b} \cdot \operatorname{Cos} \theta_{\text {na.nb }}}{\operatorname{Sin} \Psi_{5} \cdot \operatorname{Sin} 2 \theta_{\text {na.nb }}} \\
& B=\frac{\operatorname{Cos} \Psi_{\mathrm{b}}-\operatorname{Cos} \Psi_{\mathrm{a}} \cdot \operatorname{Cos} \theta_{\text {na.nb }}}{\operatorname{Sin} \Psi_{5} \cdot \operatorname{Sin} 2 \theta_{\text {na.nb }}}
\end{aligned}
$$

where, The $\mathrm{X}, \mathrm{Y}, \mathrm{A}$, and $\mathrm{B}$ are dimensionless factors which depend upon the geometry of the wedge; $\Psi_{\mathrm{a}}$ and $\Psi_{\mathrm{b}}$ are the dips of planes A and B respectively; na-pole of plane $\mathrm{A} ; \mathrm{nb}$-pole of plane $\mathrm{B} ; 1$-intersection of plane $\mathrm{A}$ with the slope face; 2 -intersection of plane B with the slope face; 3-intersection of plane A with upper slope surface; 4intersection of plane B with upper slope surface; and $\Psi_{5}$ is the dip of the line of intersection of Planes A and B. The required angles can be measured on a stereoplot of the data which plotted using the geometry of the wedge and the slope.

\section{Results and discussion}

\section{Landslide hazard zonation (LHZ) mapping}

The facet-wise ratings of all the causative factors were evaluated as per the LHEF rating scheme [11]. The facet 2 was assigned the highest rating of 1.00 for lithology, next the facet 4 and facet 3 was assigned the rating of 0.94 and 0.90 respectively. The evaluation of structural ratings involves the field measurements of structural discontinuities and slope orientation Table 5. These measurements were used to plot stereonet to evaluate facetwise structural ratings through relationships of the discontinuity with the slope (Fig. 2). On the basis of the stereo-net plot, the structural rating values were calculated as per the BIS norms. Facet 3 has the highest structural rating of 1.05. The Facet 2 and 4 have the moderate structural rating of 0.67 and 0.68 respectively. The slope morphometry analyses in the study area reveal gentle slope $\left(16^{\circ}-25^{\circ}\right)$ and very gentle slope $\left(\leq 15^{\circ}\right)$ categories are exists along the ghat road. The LHEF rating for gentle slope (facet $2,3,4$, and facet 5 ) was awarded as 0.8 , and for very gentle slope (facets 1 ) the rating of 0.5 was assigned. The relative relief of the individual facet reveals that the facet 2 having the high relief was assigned the rating of 0.5 , while all other facets possess the moderate relief was assigned the ratings of 0.3 . The fairly dense scrub and forest plantation are the land use and land cover features 
Table 5 Facet wise geometry of structural discontinuities

\begin{tabular}{|c|c|c|c|c|c|c|}
\hline \multirow[t]{2}{*}{ Facet no. } & \multicolumn{2}{|l|}{ Location details } & \multirow{2}{*}{$\begin{array}{l}\text { Orientation } \\
\text { of slope direction } \\
\text { and inclination }\end{array}$} & \multicolumn{3}{|c|}{$\begin{array}{l}\text { Orientation of discontinuities (direction } \\
\text { and dip amount) }\end{array}$} \\
\hline & Latitude & Longitude & & Joint set-1 & Joint set-2 & Joint set-3 \\
\hline Facet-1 & $\begin{array}{l}\text { There is no rock } \\
\text { slope sections } \\
\text { found }\end{array}$ & & & & & \\
\hline \multirow[t]{4}{*}{ Facet-2 } & $11^{\circ} 45^{\prime} 16^{\prime \prime} \mathrm{N}$ & $78^{\circ} 15^{\prime} 33^{\prime \prime} \mathrm{E}$ & $\mathrm{N} 120^{\circ} / 28^{\circ}$ & $\mathrm{N} 320^{\circ} / 65^{\circ}$ & $N 173^{\circ} / 75^{\circ}$ & $N 240^{\circ} / 70^{\circ}$ \\
\hline & $11^{\circ} 45^{\prime} 22^{\prime \prime} \mathrm{N}$ & $78^{\circ} 15^{\prime} 37^{\prime \prime} \mathrm{E}$ & $\mathrm{N} 180^{\circ} / 30^{\circ}$ & $N 355^{\circ} / 49^{\circ}$ & $N 224^{\circ} / 85^{\circ}$ & - \\
\hline & $11^{\circ} 45^{\prime} 24^{\prime \prime} \mathrm{N}$ & $78^{\circ} 15^{\prime} 40^{\prime \prime} \mathrm{E}$ & $\mathrm{N} 124^{\circ} / 29^{\circ}$ & N $340^{\circ} / 39^{\circ}$ & $\mathrm{N} 150^{\circ} / 64^{\circ}$ & - \\
\hline & $11^{\circ} 45^{\prime} 34^{\prime \prime} \mathrm{N}$ & $78^{\circ} 15^{\prime} 46^{\prime \prime} \mathrm{E}$ & $N 148^{\circ} / 28^{\circ}$ & $\mathrm{N} 240^{\circ} / 65^{\circ}$ & - & - \\
\hline \multirow[t]{3}{*}{ Facet-3 } & $11^{\circ} 45^{\prime} 52^{\prime \prime} \mathrm{N}$ & $78^{\circ} 15^{\prime} 55^{\prime \prime} \mathrm{E}$ & $\mathrm{N} 185^{\circ} / 26^{\circ}$ & $\mathrm{N} 85^{\circ} / 30^{\circ}$ & $N 250^{\circ} / 62^{\circ}$ & - \\
\hline & $11^{\circ} 46^{\prime} 04^{\prime \prime} \mathrm{N}$ & $78^{\circ} 16^{\prime} 04^{\prime \prime} E$ & $\mathrm{~N} 115^{\circ} / 25^{\circ}$ & $\mathrm{N} 25^{\circ} / 78^{\circ}$ & $N 350^{\circ} / 74^{\circ}$ & $\mathrm{N} 135^{\circ} / 65^{\circ}$ \\
\hline & $11^{\circ} 46^{\prime} 09^{\prime \prime} \mathrm{N}$ & $78^{\circ} 16^{\prime} 04^{\prime \prime} \mathrm{E}$ & $\mathrm{N} 95^{\circ} / 27^{\circ}$ & $\mathrm{N} 345^{\circ} / 80^{\circ}$ & $N 295^{\circ} / 25^{\circ}$ & $\mathrm{N} 115^{\circ} / 15^{\circ}$ \\
\hline \multirow[t]{3}{*}{ Facet-4 } & $11^{\circ} 46^{\prime} 19^{\prime \prime} \mathrm{N}$ & $78^{\circ} 16^{\prime} 06^{\prime \prime} E$ & $\mathrm{~N} 120^{\circ} / 30^{\circ}$ & $N 225^{\circ} / 58^{\circ}$ & $\mathrm{N} 85^{\circ} / 75^{\circ}$ & - \\
\hline & $11^{\circ} 46^{\prime} 26^{\prime \prime} \mathrm{N}$ & $78^{\circ} 16^{\prime} 26^{\prime \prime} \mathrm{E}$ & $N 75^{\circ} / 25^{\circ}$ & $\mathrm{N} 125^{\circ} / 80^{\circ}$ & - & - \\
\hline & $11^{\circ} 46^{\prime} 31^{\prime \prime} \mathrm{N}$ & $78^{\circ} 16^{\prime} 11^{\prime \prime} E$ & N $165^{\circ} / 19^{\circ}$ & $\mathrm{N} 215^{\circ} / 80^{\circ}$ & $N 155^{\circ} / 58^{\circ}$ & - \\
\hline Facet-5 & $\begin{array}{l}\text { There is no rock } \\
\text { slope sections } \\
\text { found }\end{array}$ & & & & & \\
\hline
\end{tabular}

present in the study area. The LHEF rating of 0.80 has given to the facets $1,2,3$ and 4 with fairly dense scrub, whereas the facet 5 mixed with fairly dense scrub and forest plantation area of has assigned 0.7. Facet wise evaluations of the ratings for hydrogeological conditions over rock and soil slope locations are visually observed and estimated ratings reveals the facets 3 have the maximum ratings of 1.50. The facets 4 and 2 possess the moderate rating for hydrogeological conditions as 1.28 and 1.13 respectively, while facet 5 was assigned the rating of 0.75 . The LHZ map was prepared by calculating the TEHD by adding the ratings of all the causative factors (Fig. 3) and corrections due to triggering factors within a facet. Based on the LHEF rating scheme, the TEHD values were evaluated for all the five facets. The ratings for individual causative factors in each facet, TEHD, corrected TEHD, and hazard zones are given in Table 6. The landslide hazard zonation mapping for the Yercaud (alternate) ghat road section indicates that, out of five facets, facet 3 falls in high hazard zone (HHZ) category, facet 2 and 4 falls in moderate hazard zone (MHZ) category and the facet 1 and 5 falls in very low hazard zone (VLHZ) category (Fig. 4).

\section{Slope stability analyses of rock sections}

The detailed slope stability analyses were carried out on selected rock slope sections along Kuppanur-Kotanchedu ghat road section. For this detailed study, three facet sections were selected respectively from moderate hazard zones (facet 2 and 4) and high hazard zone (facet 3) along Yercaud (alternate) ghat road. The slope stability analyses of rock slope sections were carried out over this moderate and high hazard zones. These RS sections were identified based on appropriate slope amount, height, presence of discontinuities and its conditions. In these three facets, six potential rock slope (RS) sections were identified from facet 2 and facet 3 for RMR, SMR and FOS analyses are shown in Fig. 1.

The RMR parameters are measured for each structural unit in the field and recorded in field data sheet. The samples were collected from the field for compressive strength 

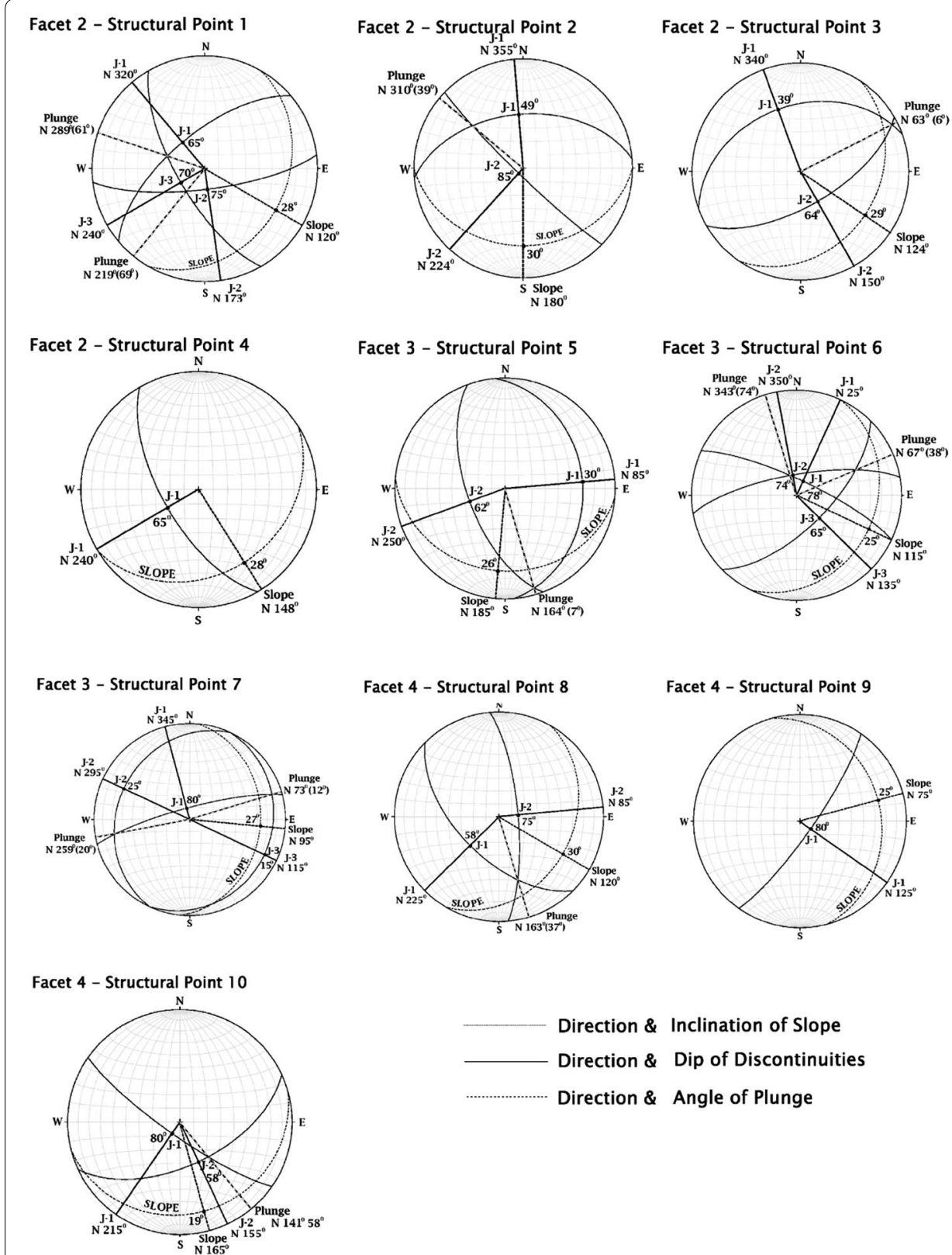

Fig. 2 Stereonet plots of structural points from facet-2, 3, and 4 used to evaluate the structural rating

(Point Load Test) analysis. The RS-4 has minimum compressive strength of $4.7755 \mathrm{Mpa}$ while the RS-3 has maximum compressive strength of $10.088 \mathrm{Mpa}$. Based on the parameters observed in the field and point load test, the ratings were assigned according to the rock mass rating [10]. The total RMR value is calculated by means of algebraic sum of RMR parameters. The area depicts class III (RS-1, 2, 4, 5, 6) and class IV (RS-3) of RMR classes. The result of RMR indicated that the rock sections 1, 2, 4, 5 and 6 fall in fair rock class and rock section 3 classified as poor rock type. The RMR values, ratings of observed parameters and their class description, cohesion of rock mass, and angle of internal friction of rock mass of selected rock sections are given in Table 7. 


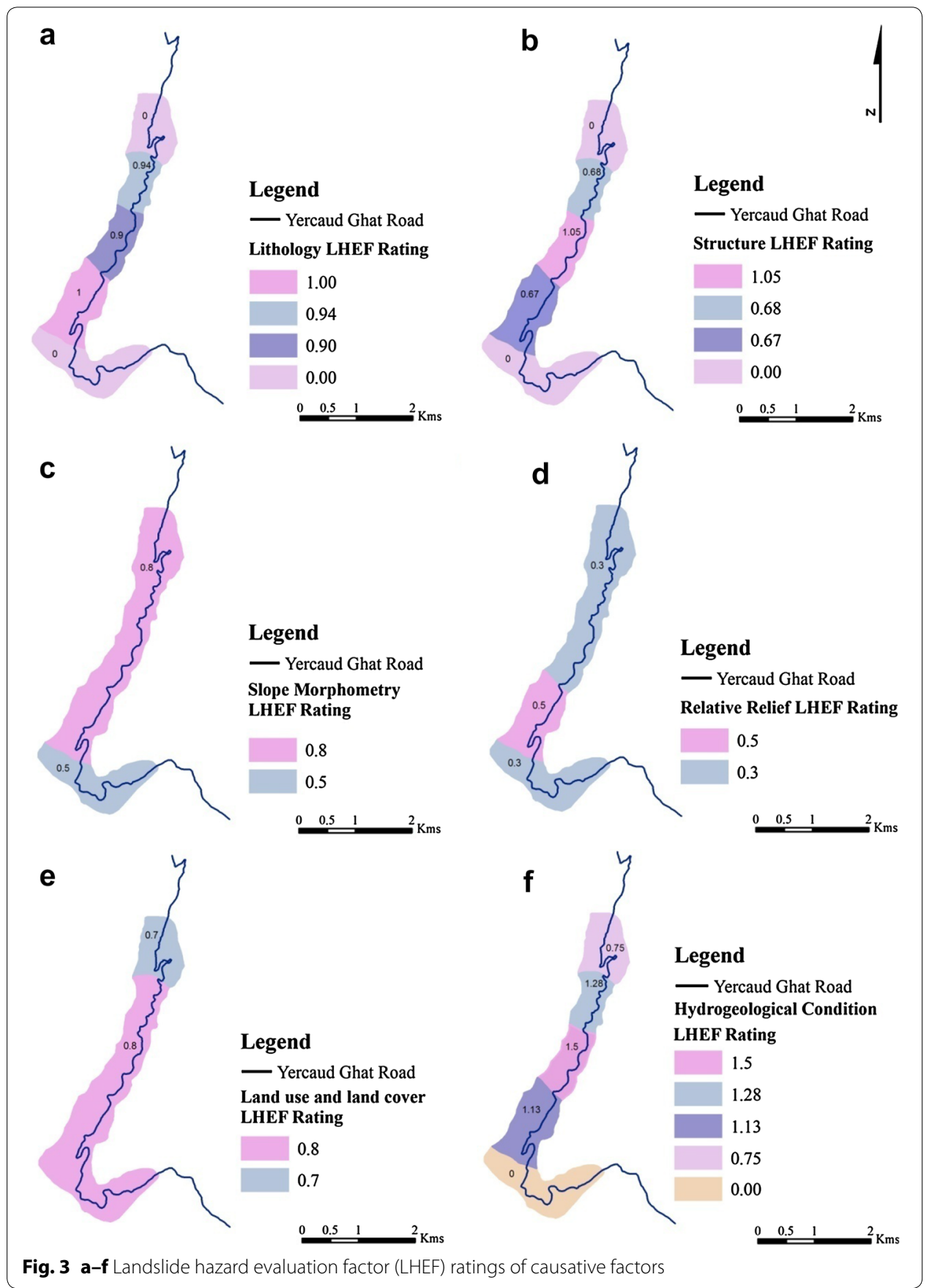

In the field, the orientation of discontinuities (strike, dip amount and dip direction) are measured for all the selected RS sections. The structural values of all the RS sections and their discontinuities are plotted on the stereonet plot, to find the type of failure and plunge of discontinuity. The relationship between the slope and discontinuities was made to determine the adjustment ratings for F1, F2, and F3. In the study area, the cut slopes are formed by mechanical excavation of slopes, and is often combined with some preliminary blasting. This method of excavation neither increases nor decreases the slope stability, so the adjustment factor for F4 is given as 0. These F1, F2, F3, and F4 


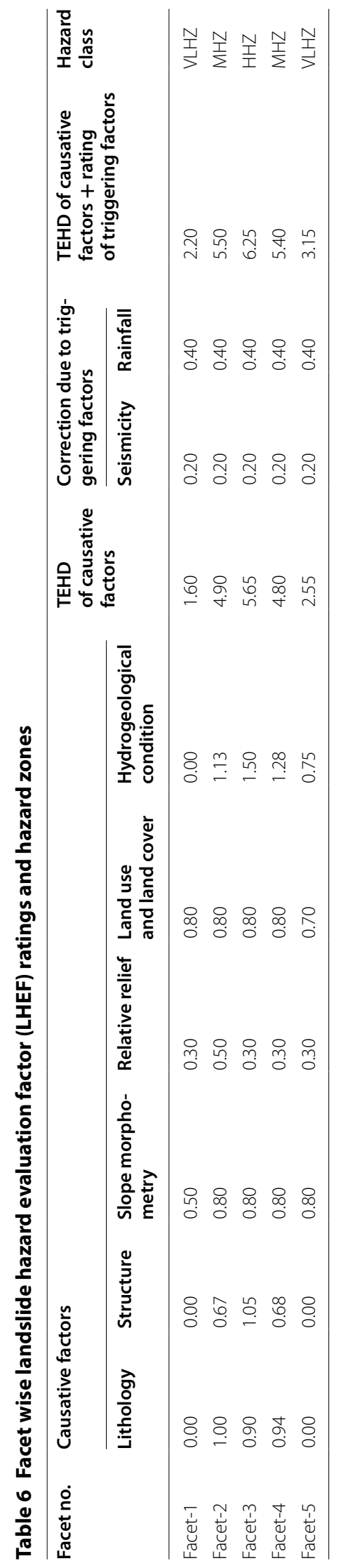




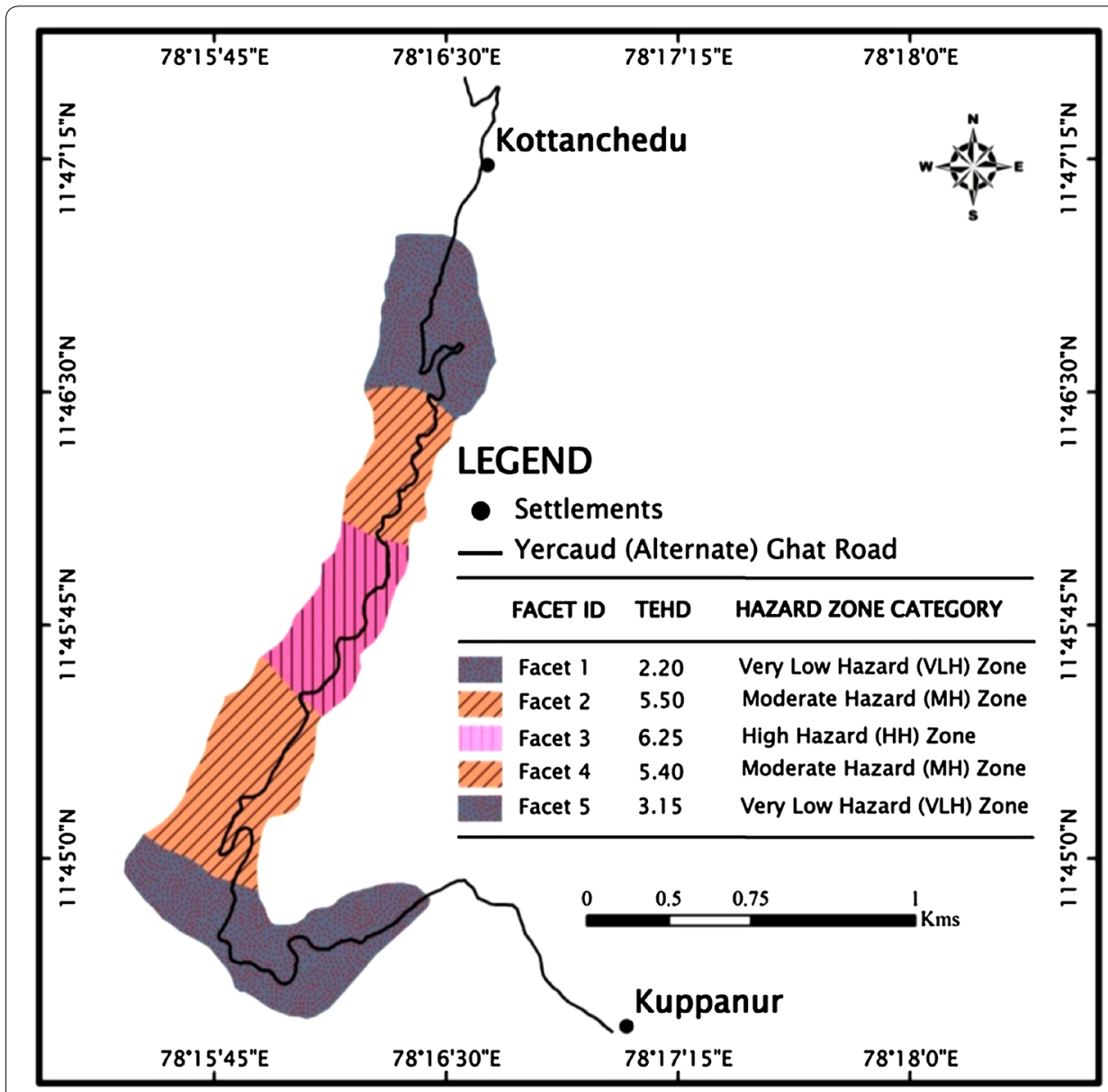

Fig. 4 Landslide hazard zonation map of the Kuppanur-Yercaud ghat road section

values were added with the RMR basic value to find the SMR values. The results of SMR values, class, description, stability, probable type of failure and supportive measures are shown in the Table 8.

The stability analyses of critical discontinuity sets from RS section were identified for planar as well as wedge mode of failure conditions. The FOS for planar and wedge type of failure modes was evaluated using Hoek and Bray Eqs. 4 and 9 respectively. The structural readings (slope and joint set), friction angle values were plotted in the Stereonet and made analysis to find out the possible failure modes i.e. type of failure. The possible critical failure modes and critical discontinuity sets from all the sections were identified and given in the Table 9. The input parameters required for the evaluation of FOS of planar and wedge types of failures were derived from the stereoplots shown in Fig. 5. The calculation of FOS of RS-3 (planar failure) and RS-6 (wedge failure) is given in Tables 10 and 11 respectively. The planar analysis of RS-1, RS-2, RS-3, RS-5 and RS- 6 gives the FOS values of $4.65,-1.58,0.53,2.28$ and 4.82 respectively. The FOS of wedge analysis for sections RS-4 and RS- 6 are 11.54 and 26.31 respectively. The results based on planar failure analysis the RS-2 and RS-3 having FOS $<1$ under the tension crack is completely filled with water condition. Hence, the sections are more unstable for slope failure. The wedge failure analysis shows that all the rock sections having FOS $>1$ fall in safe conditions. 


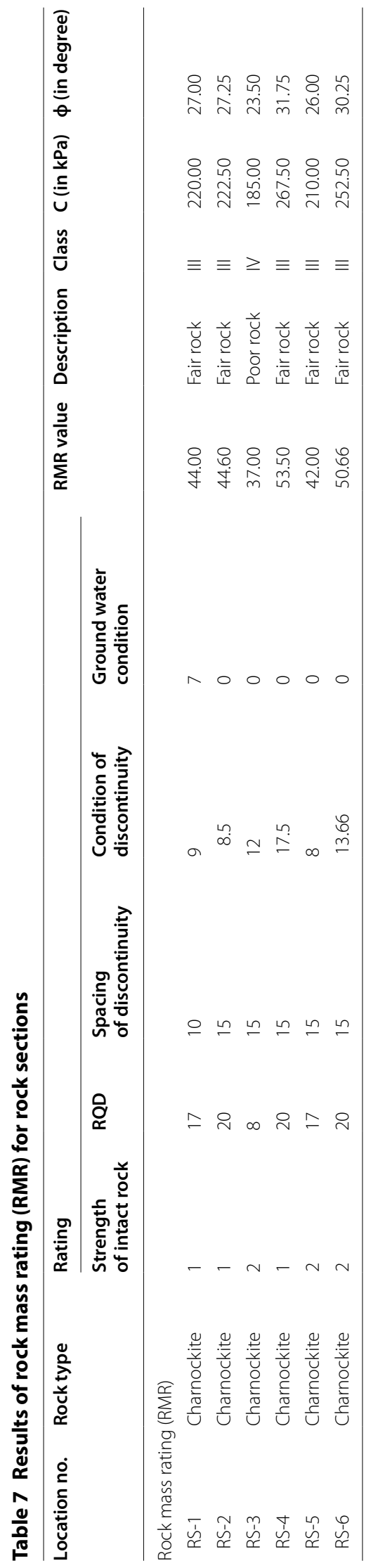


Table 8 Results of slope mass rating (SMR) for rock sections

\begin{tabular}{|c|c|c|c|c|c|c|}
\hline Rock section & RS-1 & RS-2 & $\mathrm{RS}-3$ & $\mathrm{RS}-4$ & RS-5 & RS-6 \\
\hline Class no & III & III & IV & III & III & III \\
\hline SMR & 44.00 & 44.60 & 37.00 & 49.90 & 42.00 & 48.62 \\
\hline Description & Normal & Normal & Bad & Normal & Normal & Normal \\
\hline Stability & Partially stable & Partially stable & Unstable & Partially stable & Partially stable & Partially stable \\
\hline $\begin{array}{l}\text { Probable type } \\
\text { of failure }\end{array}$ & $\begin{array}{l}\text { Planar or } \\
\text { many } \\
\text { wedges }\end{array}$ & $\begin{array}{l}\text { Planar or } \\
\text { many } \\
\text { wedges }\end{array}$ & $\begin{array}{l}\text { Planar or big } \\
\text { wedge }\end{array}$ & $\begin{array}{c}\text { Planar or } \\
\text { many } \\
\text { wedges }\end{array}$ & $\begin{array}{c}\text { Planar or } \\
\text { many } \\
\text { wedges }\end{array}$ & $\begin{array}{c}\text { Planar or many } \\
\text { wedges }\end{array}$ \\
\hline Support & $\begin{array}{r}\text { Systematic } \\
\text { supports }\end{array}$ & $\begin{array}{r}\text { Systematic } \\
\text { supports }\end{array}$ & $\begin{array}{l}\text { Important } \\
\text { corrective } \\
\text { measures }\end{array}$ & $\begin{array}{r}\text { Systematic } \\
\text { supports }\end{array}$ & $\begin{array}{c}\text { Systematic } \\
\text { support }\end{array}$ & $\begin{array}{c}\text { Systematic } \\
\text { support }\end{array}$ \\
\hline
\end{tabular}

Table 9 Identified critical sections for factor of safety analyses

\begin{tabular}{llc}
\hline Mode of failure & Section ID & Joint sets \\
\hline Planar failure & Rock section-1 & Joint set 2 \\
& Rock section-2 & Joint set 2 \\
& Rock section-3 & Joint set 2 \\
& Rock section-5 & Joint set 1 \\
Wedge failure & Rock section-6 & Joint set 3 \\
& Rock section-4 & Joint set 1 and 2 \\
& Rock section-6 & Joint set 1 and 3 \\
\hline
\end{tabular}

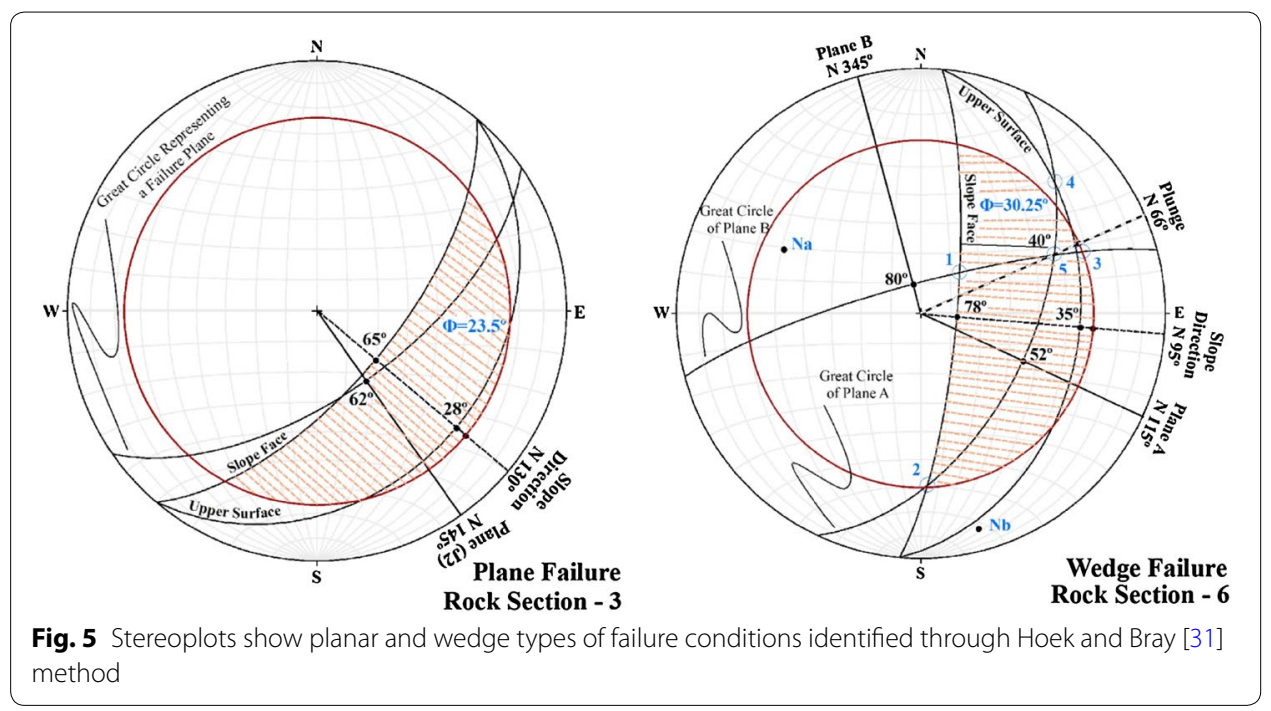

\section{Conclusion and recommendations}

The landslide hazard zonation mapping carried-out by considering lithology, structure, slope morphometery, relative relief, land use and land cover, and hydrological conditions has indicated that facet 1 and 5 are categorized under very low hazard zone (VLHZ). The facet 2 and 4 are categorized under moderate hazard zone (MHZ). The facet 3 classified under high hazard zone (HHZ). Based on the analyses of LHEF rating values of each facet 
Table 10 Calculation of factor of safety-rock section-3 (planar failure)

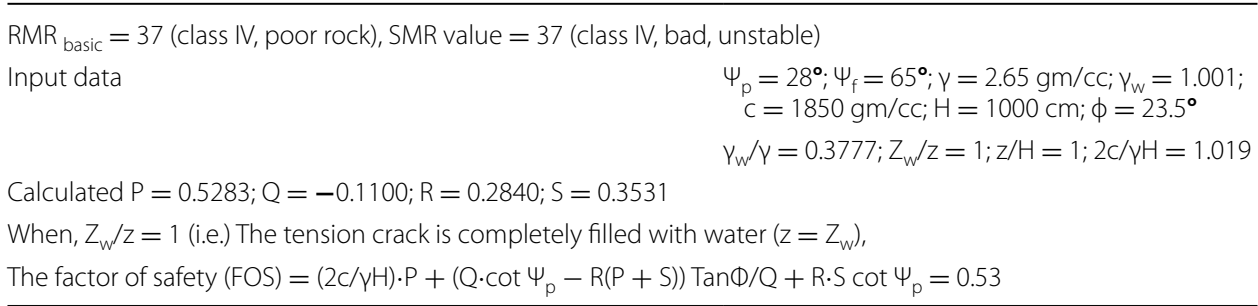

Table 11 Calculation of factor of safety-rock section-6 (wedge failure)

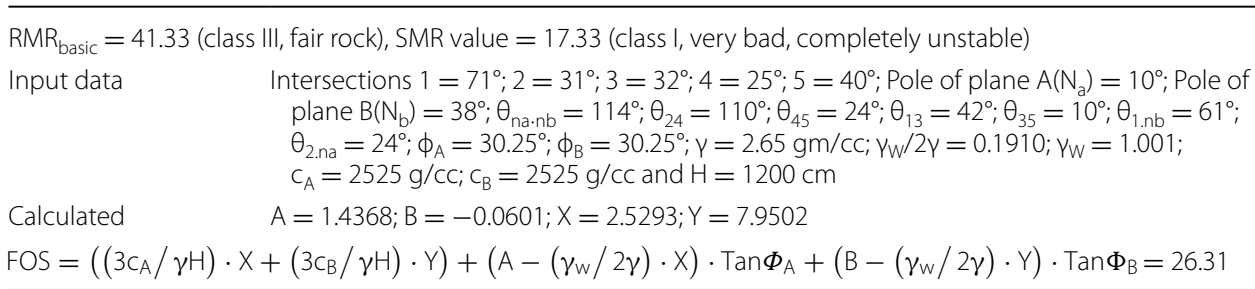

indicates that the weathering, structural discontinuities, slope morphometry, relief and hydrogeological conditions are the major causative factors for occurrence of landslides. The output is useful to carry out proper preventative and restoration process to avoid occurrence of landslide in future. This has indicated that the necessity of conducting a detailed geotechnical studies to prevent or minimize the slope failures. The result of RMR indicated that the rock sections 1, 2, 4, 5 and 6 fall in fair rock class and rock section 3 classified as poor rock type. The result of SMR has indicated that the rock sections 1, 2, 4, 5 , and 6 classified as partially stable, rock sections 3 categorized as unstable. The F calculated for critical sections, which is identified through slope-joint relationship from stereonet plot. The FOS was calculated based on Hoek and Bray [31] method. In planar failure case, the FOS for RS-2 and RS-3 show values $<1$ FOS indicating that more critical condition for slope failures. While in the case of wedge failure, the FOS is $>1$ indicating that the slopes RS-4 and RS-6 are safe for wedge mode of failure. Based on this study, the rock section falling under partially stable category requires systematic supports. The unstable section RS-3 requires important corrective measures. Overall, the study has provided detail rock mass classification information on the section and location of slope failures along ghat road of Yercaud hills. The output is useful to carryout proper preventative and restoration process to avoid occurrence of landslides in future.

Authors' contributions

SA supervised the research work and participated in amending the manuscript. VR, SM, MB, and GK carried out the field work, data and sample collection, laboratory analyses, GIS work, and preparation of manuscript. All authors read and approved the final manuscript.

\section{Author details}

${ }^{1}$ Centre for Geoinformatics and Planetary Studies, Periyar University, Salem, Tamil Nadu 636011 , India. ${ }^{2}$ Centre for Geoinformatics, Jamsetji Tata School of Disaster Studies, Tata Institute of Social Sciences (TISS), Deonar Farm Road, Deonar, Post Box No: 8313, Mumbai 400088, Maharashtra, India. ${ }^{3}$ School of Civil Engineering, SASTRA University, Thirumalaisamudram, Thanjavur 613401, India. 


\section{Competing interests}

The authors declare that they have no competing interests.

Received: 30 July 2016 Accepted: 31 January 2017

Published online: 20 February 2017

\section{References}

1. Ahmad M, Ansari MK, Singh TN (2013) Instability investigations of basaltic soil slopes along SH-72, Maharashtra, India. Geomat Nat Hazards Risk 6(2):115-130. doi:10.1080/19475705.2013.826740

2. Aleotti P, Chowdhury R (1999) Landslide hazard assessment: summary review and new perspectives. Bull Eng Geol Environ 58(1):21-44. doi:10.1007/s100640050066

3. Anbalagan R (1992) Landslide hazard evaluation and zonation mapping in mountainous terrain. Eng Geol 32(4):269-277. doi:10.1016/0013-7952(92)90053-2

4. Anbalagan R, Chakraborty D, Kohli A (2008) Landslide hazard zonation (LHZ) mapping on meso-scale for systematic town planning in mountainous terrain. J Sci Ind Res 67:486-497

5. Anbazhagan S, Ramesh V (2014) Landslide Hazard zonation mapping in ghat road section of Kolli Hills, India. J Mt Sci 11(5):1308-1325. doi:10.1007/s11629-012-2618-9

6. Armaş I, Vartolomei F, Stroia F, Braşoveanu L (2014) Landslide susceptibility deterministic approach using geographic information systems: application to Breaza town, Romania. Nat Hazards 70(2):995-1017. doi:10.1007/ s11069-013-0857-x

7. Balamurugan $G$, Ramesh $V$, Touthan M (2016) Landslide susceptibility zonation mapping using frequency ratio and fuzzy gamma operator models in part of NH-39, Manipur, India. Nat Hazards 84(1):465-488. doi:10.1007/ s11069-016-2434-6

8. Bieniawski ZT (1973) Engineering classification of jointed rock masses. Trans S Afr Inst Civ Eng 15(12):344-355

9. Bieniawski ZT (1976) Rock mass classification in rock engineering. In: Bieniawski ZT (ed) Exploration for rock engineering. Proceedings of the symposium exploration rock engineering Johannesburg, pp 97-106

10. Bieniawski ZT (1989) Engineering rock mass classifications. Wiley, Chichester, p 251

11. BIS (1998) Bureau of Indian Standard (1998) IS: 14496, preparation of landslide hazard zonation maps in mountainous terrains - guidelines, Part 2 Macro-zonation BIS, New Delhi

12. Capecchi F, Focardi P (1988) Rainfall and landslides: research into a critical precipitation coefficient in an area of Italy In: Bonnard C (ed) Proceedings of the 5th international symposium on landslides. A.A. Balkema, Lausanne, Rotterdam, pp 1031-1136

13. Chauhan S, Sharma M, Arora MK, Gupta NK (2010) Landslide susceptibility zonation through ratings derived from artificial neural network. Int J Appl Earth Obs Geoinf 12(5):340-350. doi:10.1016/j.jag.2010.04.006

14. Chen Z (1995) Recent developments in slope stability analysis. In: Fujii T (Ed) Keynote lecture. Proceedings of 8th international congress on rock mechanics, vol 3, pp 1041-1048

15. Choi J, Oh HJ, Lee HJ, Lee C, Lee S (2012) Combining landslide susceptibility maps obtained from frequency ratio, logistic regression, and artificial neural network models using ASTER images and GIS. Eng Geol 124(4):12-23. doi:10.1016/j.enggeo.2011.09.011

16. Colombo A, Lanteri L, Ramasco M, Troisi C (2005) Systematic GIS based landslide inventory as the first step for effective landslide hazard management. Landslides 2:291-301. doi:10.1007/s10346-005-0025-9

17. Dahl M, Mortensen L, Veihe A, Jensen N (2010) A simple qualitative approach for mapping regional landslide susceptibility in the Faroe Islands. Nat Hazards Earth Syst Sci 10:159-170. doi:10.5194/nhess-10-159-2010

18. Dai FC, Lee CF, Ngai YY (2002) Landslide risk assessment and management: an overview. Eng Geol 64(1):65-87. doi:10.1016/S0013-7952(01)00093-X

19. Das I, Stein A, Kerle N (2011) Probabilistic landslide hazard assessment using homogeneous susceptible units (HSU) along a national highway corridor in the northern Himalayas, India. Landslides 8(3):293-308. doi:10.1007/ s10346-011-0257-9

20. Devkota KC, Kim GW, Lee HN, Ham JE (2009) Characteristics of discontinuity spacing in a rock mass. In: Proceedings of the international conference on rock joints and jointed rock masses, Tucson, Arizona, USA, January 7-8

21. Devoli G, Morales A, Hoeg K (2007) Historical landslides in Nicaragua_collection and analysis of data. Landslides 4(1):5-18. doi:10.1007/s10346-006-0048-x

22. Galli M, Ardizzone F, Cardinali M, Guzzetti F, Reichenbach P (2008) Comparing landslide inventory maps. Geomorphology 94:268-289. doi:10.1016/j.geomorph.2006.09.023

23. Ghosh S (2011) Knowledge guided empirical prediction of landslide hazard. PhD thesis, University of Twente, The Netherlands, p 13

24. GSI (1995) Geological and mineral resources map of Tamil Nadu and Pondicherry, Geological Survey of India

25. GSI Report (2006) Geology and mineral resources of the states of India. Part IV-Tamil Nadu and Pondicherry, Geological Survey of India

26. Guzzetti F, Carrara A, Cardinalli M (1999) Landslide hazard evaluation: a review of current techniques and their application in a multi-case study, Central Italy. Geomorphology 31:181-216. doi:10.1016/S0169-555X(99)00078-1

27. Hack HR (1998) Slope stability probability classification ITC Delf publication. ITC Enschede, Enschede, p 273

28. Hack R, Price D, Rengers NA (2003) A new approach to rock slope stability-a probability classification (SSPC). Bull Eng Geol Environ 62(2):167-184. doi:10.1007/s10064-002-0155-4

29. Haines A, Terbrugge PJ (1991) Preliminary estimation of rock slope stability using rock mass classification system, In: Wittke W (Ed) Proceedings 7th congress on rock mechanics, ISRM Rotterdam, pp 887-892

30. Hock E, Bray JW, Boyd JM (1973) The stability of a rock slope containing a wedge resting on two intersecting discontinuities. Q J Eng Geol 6:1-55. doi:10.1144/GSL.QJEG.1973.006.01.01 
31. Hoek E, Bray JW (1981) Rock slope engineering. Stephen Austin \& Sons Limited Publishers, Hertford

32. Jaiswal P, van Westen CJ (2009) Estimating temporal probability for landslide initiation along transportation routes based on rainfall thresholds. Geomorphology 112:96-105. doi:10.1016/j.geomorph.2009.05.008

33. Kannan M, Saranathan E, Anbalagan R (2011) Macro landslide hazard zonation mapping — case study from BodiBodimettu ghat section, Theni District, Tamil Nadu, India. J Indian Soc Remote Sens 39(4):485-496. doi:10.1007/ s12524-011-0112-4

34. Kanungo DP, Arora MK, Sarkar S (2009) Landslide susceptibility zonation (LSZ) mapping —a review. J South Asia Disaster Stud 2(1):81-105

35. Kumar K, Devrani R, Kathait A, Aggarwal N (2012) Micro-hazard evaluation and validation of landslide in a part of North Western Garhwal Lesser Himalaya, India. Int J Geomat Geosci 2(3):878-891

36. Kumar R, Anbalagan R (2015) Landslide susceptibility zonation in part of Tehri reservoir region using frequency ratio, fuzzy and GIS. J Earth Syst Sci 124(2):431-448. doi:10.1007/s12040-015-0536-2

37. Laubscher DH (1990) A geomechanical classification system for the rating of rock mass in mine design. J S Afr Inst Min Metall 90:257-273

38. Lindsay P, Campbell RN, Fergusson DA, Gillard GR, Moore TA (2001) Slope stability probability classification, Waikato Coal Measures, New Zeland. Int J Coal Geol 45:127-145

39. Mantovani F, Soeters R, Van Westen CJ (1996) Remote sensing techniques for landslide studies and hazard zonation in Europe. Geomorphology 15(3-4):213-225. doi:10.1016/0169-555X(95)00071-C

40. Martelloni G, Segoni S, Fanti R, Catani F (2012) Rainfall thresholds for the forecasting of landslide occurrence at regional scale. Landslides 9(4):485-495. doi:10.1007/s10346-011-0308-2

41. McKean J, Buechel S, Gaydos L (1991) Remote sensing and landslide hazard assessment. Photogramm Eng Remote Sens 57(9):1185-1193. doi:10.1109/TGRS.2011.2165547

42. Miller S, Brewer T, Harris N (2009) Rainfall thresholding and susceptibility assessment of rainfall-induced landslides: application to landslide management in St Thomas, Jamaica. Bull Eng Geol Environ 68:539. doi:10.1007/ s10064-009-0232-z

43. Moeyersons J, Tréfois Ph, Lavreau J, Alimasi D, Badriyo I, Mitima B, Mundala M, Munganga DO, Nahimana L (2004) A geomorphological assessment of landslide origin at Bukavu, Democratic Republic of the Congo. Eng Geol 72:73-87. doi:10.1016/j.enggeo.2003.06.003

44. Mostyn GR, Fell R (1997) Quantitative and semiquantitative estimation of the probability of landslides. In: Cruden D, Fell R (eds) Landslide risk assessment. Balkema, Rotterdam, pp 297-315

45. Nandi A, Shakoor A (2008) Application of logistic regression model for slope instability prediction in Cuyahoga river watershed, Ohio, USA. Georisk 2(1):16-27. doi:10.1080/17499510701842221

46. Naranjo JL, Van Westen CJ, Soeters R (1994) Evaluating the use of training areas in bivariate statistical landslide hazard analysis—a case study in Columbia. ITC J 3:292-300

47. Palmstrom A (1982) The volumetric joint count-a useful simple measure of the degree of rock jointing. In: Proceedings of 4th congress IAEG, Delhi, vol 5, pp 221-228

48. Pande RK, Burman D, Singh R (2009) Landslide hazard zonation in Hanuman Chatti area of Uttarakhand, India. Disaster Prev Manag 18(4):410-417

49. Pantelidis L (2009) Rock slope stability assessment through rock mass classification systems. Int J Rock Mech Min Sci 46(2):315-325. doi:10.1016/j.j.jrmms.2008.06.003

50. Pantelidis L (2010) An alternative rock mass classification system for rock slopes. Bull Eng Geol Environ 69(1):29-39. doi:10.1007/s10064-009-0241-y

51. Poudyal CP, Chang C, Oh HJ, Lee S (2010) Landslide susceptibility maps comparing frequency ratio and artificial neural networks: a case study from the Nepal Himalaya. Environ Earth Sci 61(5):1049-1064. doi:10.1007/ s12665-009-0426-5

52. Pradhan B, Lee S, Buchroithner MF (2009) Use of geospatial data and fuzzy algebraic operators to landslide hazard mapping. Appl Geomat 1:3-15. doi:10.1007/s12518-009-0001-5

53. Ramesh V, Anbazhagan S (2015) Landslide susceptibility mapping along Kolli hills ghat road section (India) using frequency ratio, relative effect and fuzzy logic models. Environ Earth Sci 73(12):8009-8021. doi:10.1007/ s12665-014-3954-6

54. Ramesh V, Phaomei T, Baskar M, Anbazhagan S (2016) Application of fuzzy operators in landslide susceptibility mapping along Yercaud ghat road section, Tamil Nadu, India. In: Raju NJ (ed) Geostatistical and geospatial approaches for the characterization of natural resources in the environment-challenges, processes, and strategies. Springer, Berlin, pp 545-553. doi:10.1007/978-3-319-18663-4_82

55. Regmi NR, Giardino JR, McDonald EV, Vitek JD (2014) A comparison of logistic regression-based models of susceptibility to landslides in western Colorado, USA. Landslides 11(2):247-262. doi:10.1007/s 10346-012-0380-2

56. Robertson AM (1988) Estimating weak rock strength. In: Sastry KVS (ed) Proceedings of the SME annual meeting society of mining engineering, Phoenix, pp 1-5

57. Romana M (1985) New adjustment ratings for application of Bieniawski classification to slopes. In: Proceedings of the international symposium on the role of rock mechanics in excavations for mining and civil works, international society of rock mechanics zacatecas, pp 49-53

58. Romana M (1993) A geomechanical classification for slopes: slope mass rating. In: Hudson JA (ed) Comprehensive rock engineering. Pergamon Press, Oxford, pp 575-600

59. Romana M, Serón JB, Montalar E (2001) La clasificación geomecánica SMR: aplicación experiencias y validación. In CEDEX, UPM (eds) Proceedings of the $V$ Simposio Nacional sobre taludes y laderas inestables, Centro de publicaciones, Secretaria General Técnica. Ministerio de Fomento CEDEX Madrid, pp 393-404 (in Spanish)

60. Saranathan E, Rajesh K, Kannan M (2010) Landslide macro hazard zonation of the Yercaud Hill slopes ghat sections- km 10/4 to 29/6. Indian Landslides 3(1):9-16

61. Saranathan E, Kannan M, Rajamanickam GV (2012) Assessment of landslide hazard zonation mapping in Kodaikanal, Tamil Nadu, India. Disaster Adv 5(4):42-50 
62. Sarkar S, Anbalagan R (2008) Landslide hazard zonation mapping and comparative analysis of hazard zonation maps. J Mt Sci 5:232-240. doi:10.1007/s11629-008-0172-2

63. Selby MJ (1980) A rock mass strength classification for geomorphic purposes: with test from Antarctica and New Zealand. Z Geomorphol 24:31-51

64. Sen Z, Sadagah H (2003) Modified rock mass classification system by continuous rating. Eng Geol 67:269-280 doi:10.1016/S0013-7952(02)00185-0

65. Sharma VK (2008) Macro-zonation of landslide hazard in the environs of Baira Dam Project Chamba District, Himachal Pradesh. J Geol Soc India 71(3):425-432

66. ShukT (1994) Key elements and applications of the natural slope methodology (NSM) with some emphasis on slope stability aspects. In: Proceedings of the 4 th South American congress on rock mechanics, 2. ISRM, Balkema, Rotterdam, pp 955-960

67. Shahabi H, Ahmad BB, Khezri S (2012) Evaluation and comparison of bivariate and multivariate statistical methods for landslide susceptibility mapping (case study: Zab basin). Arab J Geosci 6(10):3885-3907. doi:10.1007/ s12517-012-0650-2

68. Singh PK, Kainthola A, Singh TN (2013) Rock mass assessment along the right bank of river Sutlej. Geomat Nat Hazards Risk Online, Luhri. doi:10.1080/19475705.2013.834486

69. Srivastava V, Srivastava HP, Lakhera RC (2010) Fuzzy gamma based geomatic modeling for landslide hazard susceptibility in a part of Tons river valley, northwest Himalaya, India. Geomat Nat Hazards Risk 1(3):225-242. doi:10.1080/19 475705.2010.490103

70. Taheri A, Tani K (2010) Assessment of the stability of rock slopes by the slope stability rating classification system. Rock Mech Rock Eng 43(3):321-333. doi:10.1007/s00603-009-0050-4

71. Tangestani MH (2004) Landslide susceptibility mapping using the fuzzy gamma approach in a GIS, Kakan catchment area, southwest Iran. Aust J Earth Sci 51:439-450

72. Tomás R, Delgado J, Serón JB (2007) Modification of slope mass rating (SMR) by continuous functions. Int J Rock Mech Min Sci 44:1062-1069

73. Tomas R, Cuenca A, Cano M, Garcia-Barda J (2012) A graphical approach for slope mass rating (SMR). Eng Geol 124:67-76. doi:10.1016/j.enggeo.2011.10.004

74. Umrao RK, Singh R, Ahmad M, Singh TN (2011) Stability analysis of cut slopes using continuous slope mass rating and kinematic analysis in Rudraprayag district, Uttarakhand. Geomaterials 1:79-87. doi:10.4236/gm.2011.13012

75. Unal E (1996) Modified rock mass classification: M-RMR system. In: Bieniawski ZT (ed) Milestones in rock engineering: the Bieniawski Jubilee Collection. Balkema, Rotterdam, pp 203-223

76. Varnes DJ (1981) Slope stability problems of the circum Pacific region as related to mineral and energy resource. In: Halbouty MT (ed) Energy resources of the Pacific region. American Association of Petroleum Geologist Tulsa, Okla, pp 489-505

77. Varnes DJ (1984) Landslide hazard zonation: a review of principles and practice. Int Assoc Eng Geol UNESCO, Paris, pp 1-63

78. Wieczorek GF (1984) Preparing a detailed landslide-inventory map for hazard evaluation and reduction. Bull Assoc Eng Geol 21:337-342

79. Wines DR, Lilly PA (2002) Measurement and analysis of rock mass discontinuity spacing and frequency in part of the Fimiston Open Pit operation in Kalogeria, Western Australia: a case study. Int J Rock Mech Min Sci Geomech Abstr 39:589-602

80. Yilmaz I (2009) A case study from Koyulhisar (Sivas-Turkey) for landslide susceptibility mapping by artificial neural networks. Bull Eng Geol Environ 68(3):297-306. doi:10.1007/s 10064-009-0185-2

\section{Submit your manuscript to a SpringerOpen ${ }^{\circ}$ journal and benefit from:}

- Convenient online submission

- Rigorous peer review

- Immediate publication on acceptance

Open access: articles freely available online

- High visibility within the field

- Retaining the copyright to your article

Submit your next manuscript at $>$ springeropen.com 